\title{
A better deal for lung-diseased miners?
}

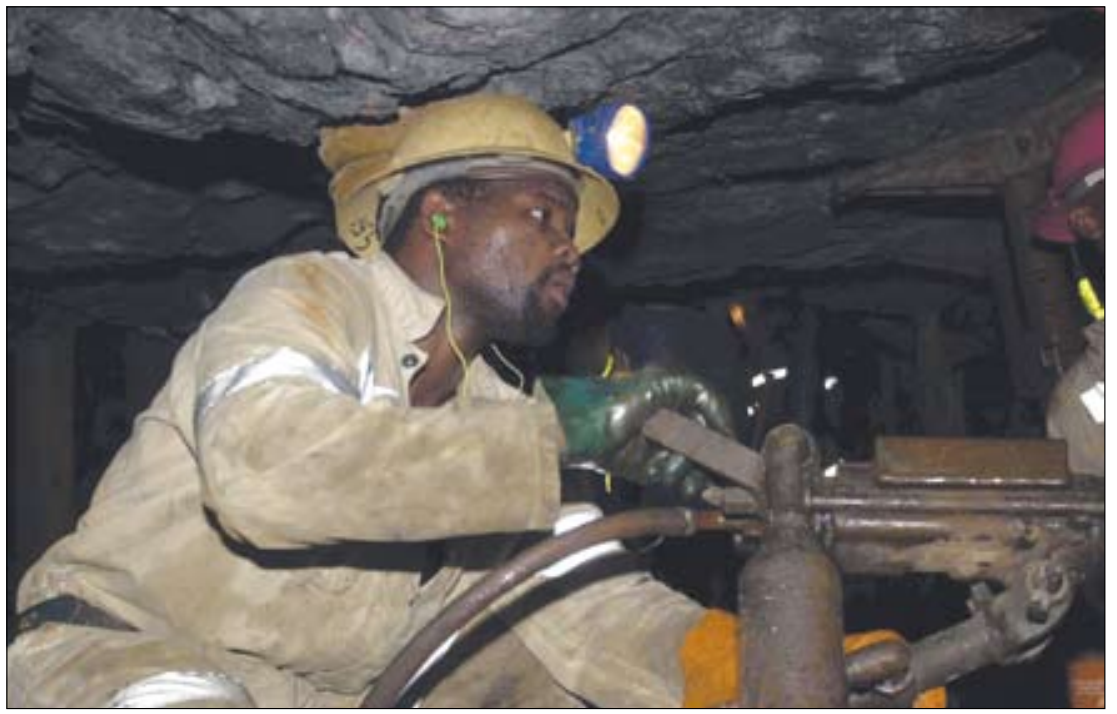

The Constitutional Court has reserved judgment in what could be a watershed case for lung-diseased former miners, epitomised by a sick Eastern Cape man who is challenging an archaic legal framework that enabled his lay-off for just R16 000.

Spoor told Izindaba that if the case failed to make history in compensating 'abused' former miners, it could at least 'jog the legislature' to equalise the legislation between mineworkers and industrial workers.

The amount represents slightly more than R1 000 for every year Thembekeli Mankayi worked for AngloGold Ashanti (dismissed in 1996 at the age of 37 when he became too ill to work). He is claiming R2.5 million for medical expenses and loss of earnings. His lawyer, the bane of mining companies and seasoned litigant, Richard Spoor, says that if Mankayi succeeds it will open the way for pay-outs worth billions of rands spread between tens of thousands of similarly affected miners. Mankayi was compensated in terms of a law which specifically and exclusively caters for (in limited terms) sick miners, the Occupational Diseases in Mines and Works Act (ODIMWA). Spoor is asking for a section in the more generalised workmen's compensation legislation that prohibits workers from suing their employers to be declared unconstitutional, claiming it tramples on Mankayi's common law rights. AngloGold Ashanti's rebuttal is that the relevant section of the ODIMWA clearly states that mineworkers with compensatable diseases are not allowed claims under the workmen's compensation act.

Spoor told Izindaba that if the case failed to make history in compensating 'abused' former miners, it could at least 'jog the legislature' to equalise the legislation between mineworkers and industrial workers.

\section{Cabinet and mines reach impasse}

'Cabinet resolved in 1998 that the two acts should be aligned but it never happened, principally because the government and the Chamber of Mines cannot agree on who will pay the additional costs associated with mineworkers,' he explained.

'Basically the laws act as a subsidy to the industry. The real cost is borne by the workers, their families and the public health system. The "polluter pays" principle should apply to occupational health but it doesn't.'

Existing mines' complaint to government is that it would be unfair for them to carry the financial can for mines that have long since stopped operating. Government on the other hand is reluctant to accept financial responsibility for laws it had no hand in making. Spoor said the workmen's compensation legislation, while marginally a 'lesser evil' than the ODIMWA, dated back to
1947 and was in dire need of urgent reform. The ODIMWA itself did not cover medical costs, failed to provide for pensions and only specified two degrees of compensation: firstor second-degree lung disease.

Spoor added: 'Basically the laws act as a subsidy to the industry. The real cost is borne by the workers, their families and the public health system. The "polluter pays" principle should apply to occupational health but it doesn't. He calculates that just $5 \%$ of the combined market capitalisation of the three biggest gold mining companies - Goldfields, Harmony and AngloGold - would establish a fund that would bring 'substantial relief' to tens of thousands of former workers.

Epidemiological studies in the former Transkei and in Botswana probing the prevalence of lung disease in ex-mineworkers and the efficiency of compensation schemes found that only a 'tiny percentage' even received what they were entitled to.

Professor Gavin Churchyard, CEO of the Aurum Institute, a not-for-profit public health benefit organisation begun by AngloGold Ashanti, puts the current HIVfuelled TB epidemic, compounded by rising drug resistance, at 3500 per 100000 mine workers, with $40 \%$ of all autopsies on men who die working on the mines revealing they had TB. ${ }^{1}$ He says the figures are far worse among workers on gold mines. AngloGold Ashanti says $15 \%$ of miners who leave their employ usually have a lung disease 'of some sort'.

Spoor said that until 1985, when the law was amended to insist on mineworkers with TB being treated before being sent home, thousands were repatriated with 'a confidence approaching certainty' that they would die. He described the pre-1985 scenario as 'a crime against humanity'. Spoor was a central litigant in the high-profile R750 million asbestosis settlements of 2005 (Cape PLC, Gencor and the Swiss multinational, Eternit (now called Anova)), and challenged economists to justify the cost of rehabilitating former asbestos mining areas.

\section{Gold mining a 'zero sum' business}

'If you look at the legacy of the asbestos industry, I'd be astonished if anyone said South Africa actually benefited,' he said. He described gold mining as a 'zero sum business', adding: 'I feel that for every dollar profit or ounce of gold in a bank vault in 


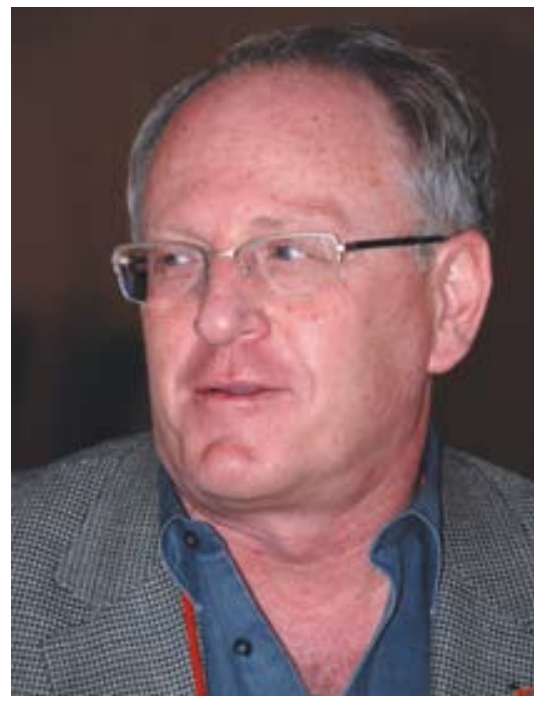

Professor Gavin Churchyard, CEO of the Aurum Institute, a not-for-profit public health benefit organisation in the mining industry.

Picture: Chris Bateman

Zurich, New York or London, somewhere in Lesotho or the former homelands people are impoverished by the same amount'.

Anyone who boasted of the 'tremendous infrastructure' the gold mines had established 'need only take a look at Virginia, Welkom and Orkney', where the infrastructural benefits associated with gold mines had collapsed.

AngloGold Ashanti says 15\% of miners who leave their employ usually have a lung disease 'of some sort'.

His client (Makanyi) and his client's community, plus the public health system, were carrying the mines' costs. 'Makanyi has had his working life cut by 25 years. The typical working lifespan of a gold miner is 17 years before they get sick, Spoor added. Viewed from this perspective a 40-year working lifetime was 'a fantasy' and exposed the miners' wages as hugely inadequate, contributing via a ripple effect to malnutrition and poverty.

Spoor said the core issue for gold mines was the prohibitive cost of improving deeplevel ventilation to the point where air that was sufficiently fresh and cold reached miners working at far greater depths than those of companies mining other minerals. He said it would cost gold mines 'four times as much' to dilute and render harmless the air and gases for its workers than it currently does to provide air cold and clean enough to prevent heat stroke at depths of up to three kilometers.

'The gold industry only operates because it's cheaper to maim and kill people. If every time you made a man sick you paid R2.5 million, 1000 such men would cost you a billion. Then you'd do something about the ventilation. As long as you're only paying around $5 \%$ of that actual harm, why should you change?' he asked.

\section{Mines respond}

In spite of being asked to respond to Spoor's more general claims and observations, a spokesperson for the Chamber of Mines declined to comment on 'matters that deal with individual mining companies'. AngloGold Ashanti spokesman, Alan Fine, said both the High Court and the Court of Appeal had found that the State had set up a compensatory system and that the quid pro quo was that this precluded the possibility of civil suits. The government had amended ODIMWA 'a couple of times' in recent years, although everyone agreed that further improvements in compensation were necessary. 'It's no different to the apartheid legacy in the sense that you can make reparations up to a point but not fully address the impact of our history. We're committed as a company and as an industry to see what needs to be done to improve things.'

\section{'The gold industry only operates because it's cheaper to maim and kill people. If every time you made a man sick you paid $\mathbf{R} 2.5$ million, 1000 such men would cost you a billion. Then you'd do something about the ventilation. As long as you're only paying around 5\% of that actual harm, why should you change?' he asked.}

'Significant strides' in engineering had recently been made to 'reduce and hopefully eliminate' the incidence of silicosis and lung disease, but these were extremely difficult to measure as lung diseases only manifested after 15 years or more. 'I don't think it's correct to say the costs of ventilation would put us out of business. Breakthroughs in engineering solutions don't necessarily come at a huge cost. What it takes is research and application and we've been doing that for a long time.' He added: 'We don't want to pretend everything's OK. It's not.'

\section{Chris Bateman}

1. Bateman C. Collaborative push to address TB crisis on mines. S Afr Med J 2009;99:852-855. 